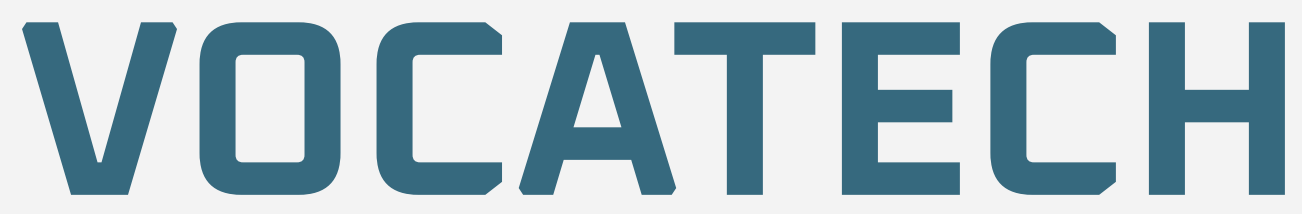

VOCATIONAL EDUCATION AND TECHNOLGY JOURNAL

Biannual

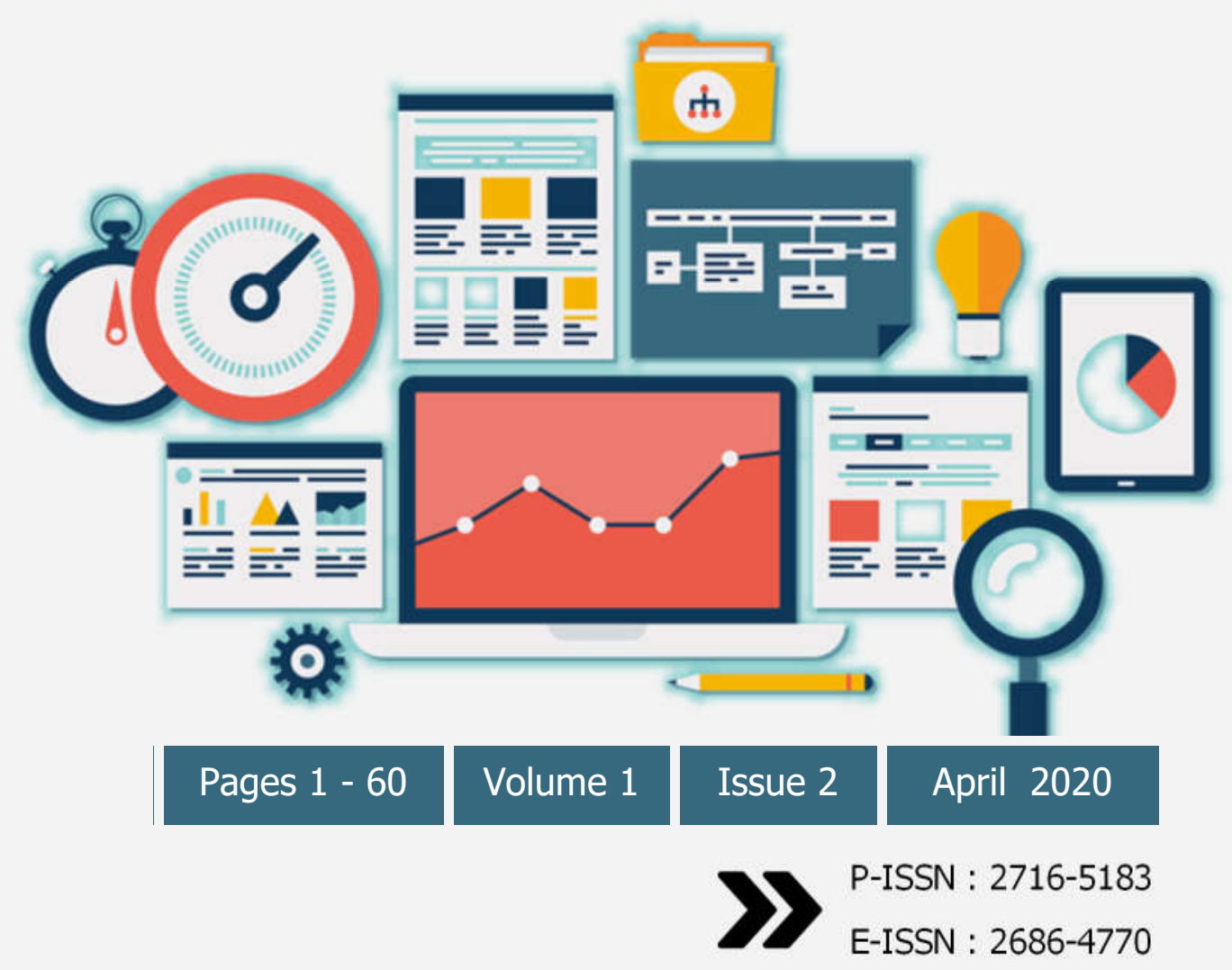

Published By: Unit Penelitian, Pengabdian Masyarakat dan Penjaminan Mutu Akademi Komunitas Negeri Aceh Barat

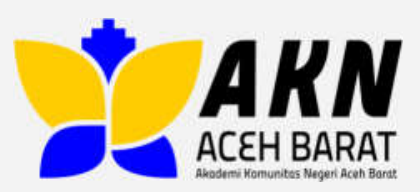




\section{P-ISSN : 2716-5183 \\ E-ISSN : 2686-4770

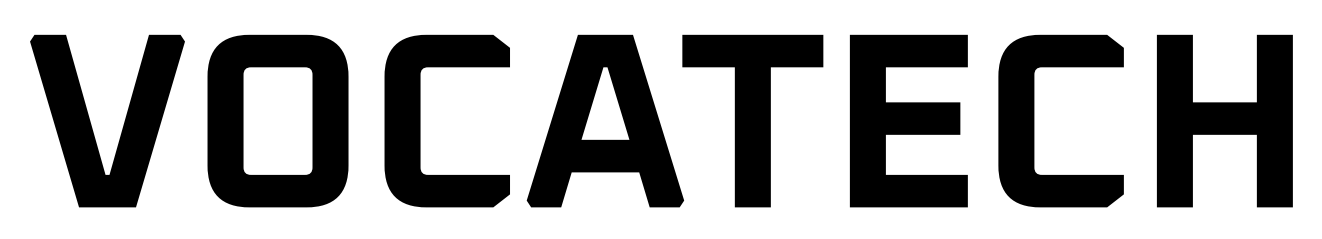

VOCATIONAL EDUCATION AND TECHNOLGY JOURNAL

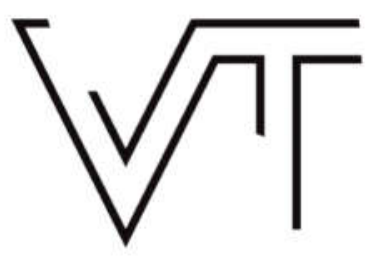

\section{Editorial Team}

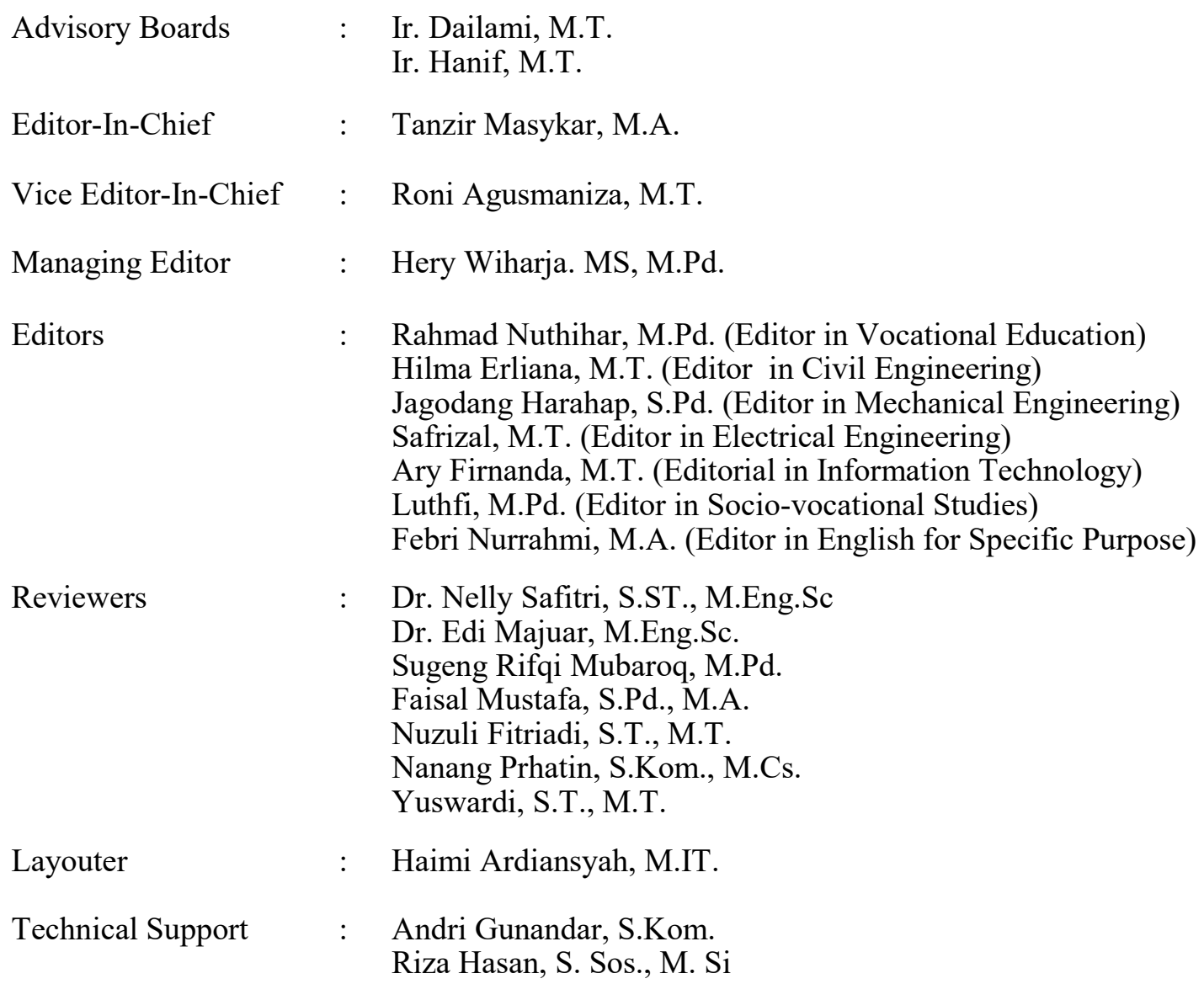

\section{Alamat Redaksi (Journal Address)}

Unit Penelitian, Pengabdian Masyarakat dan Penjaminan Mutu

Akademi Komunitas Negeri Aceh Barat

Komplek STTU Alue Peunyareng, Ujong Tanoh Darat, Meureubo, Kabupaten Aceh Barat, Aceh 23615, Indonesia

Website: http://ojs.aknacehbarat.ac.id/index.php/vocatech/index

Email:vocatech@akanacehbarat.ac.id 


\section{(2) \\ E-ISSN : 2686-4770

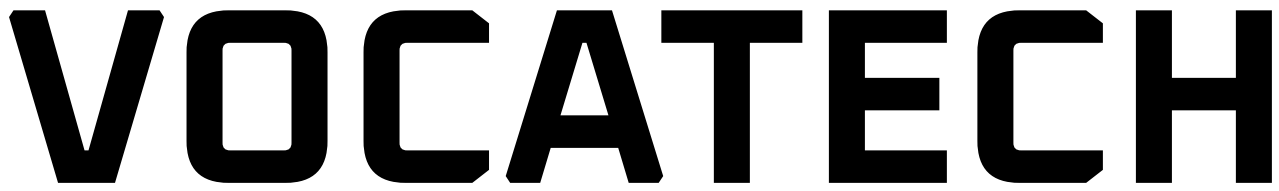 \\ VOCATIONAL EDUCATION AND TECHNOLGY JOURNAL}

\section{DAFTAR ISI (TABLE OF CONTENT)}

Pengaruh $R O E, D E R$, dan EPS Terhadap Harga Saham pada Emiten Syariah Sektor Barang

Konsumsi di BEI

—Dwi Meilvinasvita, Safaruddin, Yuliana—-

Penerapan General English dan English For Specific Purposes di Perguruan Tinggi Khususnya pada Pendidikan Vokasi

\section{—Rena Juliana, Reni Juliani-}

Pengaruh Penggunaan Kapasitor Bank pada Penyulang Kota di Pt. PLN (Persero) Rayon

Meulaboh Kota

-Haimi Ardiansyah-

Desain Alat Uji Impak Jatuh Bebas untuk Pengujian Baja Struktur

—Dailami, Hamdami, Samsul Bahri-

Analisis Kinerja Angkutan Kota dalam Provinsi di Provinsi Aceh Berdasarkan Pendekatan Load

Factor

—Ruhdi Faisal, Cut Mutiawati , Alfi Salmannur-

Klasifikasi Kematangan Buah Tomat dengan Variasi Model Warna Menggunakan Support Vector

Machine

\section{-Nica Astrianda-}

Implementasi Algoritma K-Mean dalam Pengelompokan Data Kecelakaan di Kabupaten Kediri

—Adimas Ketut Nalendra, M. Mujiono, Rafika Akhsani, Adiguna Sasama Wahyu U.- 


\title{
PENGARUH PENGGUNAAN KAPASITOR BANK PADA PENYULANG KOTA DI PT. PLN (PERSERO) RAYON MEULABOH KOTA
}

\author{
Haimi Ardiansyah \\ Akademi Komunitas Negeri Aceh Barat
}

\begin{abstract}
Penelitian ini membahas tentang pengaruh penggunaan kapasitor bank pada penyulang kota di PT. PLN (Persero) Rayon Meulaboh Kota. Pendistribusian tenaga listrik yang stabil adalah syarat mutlak yang harus dipenuhi PT. PLN (Persero) dalam menjawab kebutuhan konsumen. Bertambahnya beban yang bersifat induktif akan berpengaruh pada penurunan nilai faktor daya pada sistem kelistrikan. Selanjutnya kondisi ini juga akan membutuhkan daya reaktif yang sangat besar sehingga pembangkit listrik harus menyalurkan daya yang lebih besar. Salah satu upaya untuk memperbaiki faktor daya adalah dengan menambahkan beban kapasitif. Perbaikan faktor daya pada penyulang kota dengan menggunakan kapasitor bank bertujuan untuk meningkatkan daya aktif sehingga mendekati dengan daya semu yang diproduksi PT. PLN. Penggunakan kapasitor bank ini diharapkan mampu menurunkan daya reaktif dan memperbaiki faktor daya pada penyulang kota.
\end{abstract}

Keywords:

Daya Listrik, Daya Reaktif, Faktor daya, Kapasitor Bank

\begin{abstract}
Abstrak
The study discusses the effect of installing bank capacitor on city electric feeder at PT. PLN (Persero) Rayon Meulaboh Kota. Stable electric supply is an absolute requirement that must be met by PT. PLN (Persero) in answering consumer needs. The increase of inductive loads will affect the decrease power factor value in the electrical system. Furthermore, this condition will also require a very large reactive power so that power plants have to supply more electric power. Installing capacitive loads is one of the best options in improving the power factor. The improvement of power factor in city feeders using capacitor banks aims to increase the active power to get close to the apparent power which is produced by PT. PLN (Persero). In short, the use of capacitor banks is expected to reduce reactive power and improve the power factor in city feeders.
\end{abstract}

Kata Kunci:

Electric Power, Reactive Power, Power Factor, Capacitor Bank

Received: 19 March, 2020 ; Revised: 25 March, 2020 ; Accepted: 31 March, 2020 DOI: https://doi.org/10.38038/vocatech.v1i2.25

Corresponding author:

Haimi Ardiansyah, Program Studi Instalasi Jaringan Listrik , Akademi Komunitas Negeri Aceh Barat, Komplek STTU Alue Peunyareng, Ujong Tanoh Darat, Meureubo, Kabupaten Aceh Barat, Aceh 23615, Indonesia.

Email: haimi@aknacehbarat.ac.id

Citation in APA Style: Ardiansyah, H. (2020). Pengaruh Penggunaan Kapasitor Bank pada Penyulang Kota di PT. PLN (Persero) Rayon Meulaboh Kota. VOCATECH: Vocational Education and Technology Journal, Vol. 1 (2), 21 27. 


\section{PENDAHULUAN}

Listrik merupakan kebutuhan utama yang tidak bisa dipisahkan dari seluruh aspek kehidupan mulai dari aktivitas rumah tangga sampai dengan lingkungan industri. Distribusi tenaga listrik yang handal dan stabil dapat menentukan aktivitas rumah tangga dan industri berjalan lancar. Salah satu persyaratan sistem distribusi yang baik yang harus dipenuhi untuk kepuasan pelanggan adalah daya listrik yang stabil. Pada kenyataannya, memastikan daya listrik yang stabil adalah bukan pekerjaan yang mudah.Salah satu penyebabnya adalah karena tegangan jatuh dapat terjadi pada semua bagian sistem dan akan berubah dengan adanya perubahan jumlah beban dan panjang jaringan listrik.

Ketidakstabilan distribusi tenaga listrik tersebut tentunya dapat diatasi dengan memberikan solusi yang tepat untuk mengimbangi bertambahnya beban listrik. Diantara beban-beban yang tersambung pada sistem tenaga listrik yang paling dominan adalah beban induktif. Suatu beban dikatakan induktif apabila beban tersebut menghasilkan daya reaktif. Bertambahnya beban induktif membutuhkan daya reaktif yang sangat besar sehingga sumber pembangkit listrik pun harus mensuplai daya yang lebih besar. Keadaan seperti ini mengakibatkan jatuhnya tengangan dan faktor daya disisi lain akan membuat arus menjadi meningkat.

Salah satu solusi yang tepat dalam menjawab permasalahan di atas adalah dengan memasang kapasitor bank pada penyulang (feeder) kota. Kapasitor bank akan menurunkan daya reaktif yang disuplai ke beban pelanggan. Penurunan daya reaktif ini akan terjadi jika dapat memperbaiki/menaikkan nilai faktor daya. Dengan demikian, kondisi jatuhnya tegangan akan dapat dikurangi.

\section{STUDI PUSTAKA}

\section{A. Sistem Tenaga Listrik}

Sistem tenaga listrik merupakan sistem yang terdiri atas beberapa komponen peralatan seperti generator, transformator, beban dan alat-alat pengaman dan pengaturan yang saling dihubungkan membentuk suatu sistem yang digunakan untuk membangkitkan, dan menyalurkan energi listrik. (Gönen, 2008; Kersting, 1991) mejelaskan bahwa secara terperinci sistem tenaga listrik terbagi atas beberapa komponen utama, yaitu:

\section{Sistem Pembangkit}

Sistem pembangkit tenaga listrik (electric power station) merupakan tempat menghasilkan energi listrik yang terdapat mesin membangkitkan tenaga listrik berupa generator, dilengkapi dengan gardu induk penaik tegangan. Tegangan rendah yang dihasilkan (output) generator dinaikan menjadi tegangan tertentu dengan transformator step up (step-up transformer) sebagai penaik tegangan (Syufrijal, 2014).

\section{Sistem Transmisi}

Sistem transmisi tenaga listrik adalah seperangkat sistem yang menyalurkan energi listrik berasal dari dari pembangkit listrik yang jauh menuju gardu induk (GI). Sistem transmisi tenaga listrik ini diklasifikasikan menjadi;

- Saluran Udara Tegangan Ekstra Tinggi (SUTET)

- Saluran Udara Tegangan Tinggi (SUTT)

Sistem transmisi berfungsi untuk menyalurkan tenaga listrik dari gardu induk pusat yang terdapat pada sistem pembangkit ke gardu induk yang lain dengan jarak yang jauh (Syufrijal, 2014).

\section{Sistem Distribusi}

Sistem distribusi merupakan sistem yang menyalurkan energi listrik dari gardu induk kepada masyarakat, industri sebagai pengguna energi listrik. Berdasarkan besarnya tegangan listrik, jaringan distribusi tenaga listrik dikelompokkan menjadi 2 (dua), yaitu (Prabowo, 2016).

\section{a. Jaringan Distribusi Primer}

Jaringan distribusi primer atau sering disebut Jaringan Tegangan Menengah (JTM) terletak diantara gardu induk dengan gardu pembagi, yang memiliki tegangan sistem lebih tinggi dari tegangan terpakai untuk konsumen. Adapun besar tegangan untuk jaringan distribusi primer ini adalah $6 \mathrm{kV}, 10 \mathrm{kV}$, dan $20 \mathrm{kV}$ (standar PT. PLN).

\section{b. Jaringan Distribusi Sekunder}

Jaringan distribusi sekunder atau dengan istilah lain sering disebut sebagai Jaringan Tegangan Rendah (JTR), merupakan jaringan yang memiliki peran sebagai penyalur energi listrik dari gardu pembagi (gardu distribusi) ke pusat beban (pengguna energi listrik). Adapun nilai standar tegangan untuk jaringan distribusi 
sekunder ini adalah 127/220 V pada sistem lama, dan 220/380 V pada sistem baru untuk perumahan, serta $440 / 550 \mathrm{~V}$ untuk pemakaian di sektor industri.

\section{B. Kapasitor}

Kapasitor adalah peralatan yang digunakan untuk menyimpan muatan listrik. Sebagai akibatnya, kapasitor merupakan suatu tempat penampungan (reservoir) dimana muatan dapat disimpan dan kemudian diambil kembali. Aplikasiaplikasinya yang umum meliputi kapasitor penampung dan kapasitor penghalus yang digunakan dalam catu daya, pencampuran sinyalsinyal AC (arus bolak-balik) diantara tahapantahapan amplifier, dan pemisah sinyal-sinyal dalam catu daya. (Untamah, 2016).

\section{Kapasitor Bank}

Kapasitor bank adalah peralatan listrik untuk meningkatkan power faktor (pf), yang terdiri dari rangkaian-rangkaian kapasitor yang dirangkai dalam suatu panel yang disebut panel kapasitor bank, yang sisusun seri atau paralel dalam suatu grup dengan lapisan logam. Dalam kapasitor bank terdapat resistor yang berfungsi sebagai alat internal untuk membuang sisa tegangan (Almanda \& Majid, 2019).

\section{Faktor Daya}

Faktor daya merupakan salah satu indikator baik buruknya kualitas daya listrik. Faktor daya atau faktor kerja adalah perbandingan antara daya aktif (Watt) dengan daya semu/daya total (VA), atau cosinus sudut antara daya aktif dan daya semu/daya total. Peningkatan daya reaktif akan meningkatkan sudut antara daya aktif dan daya semu sehingga dengan daya aktif yang tetap akan mengakibatkan peningkatan daya semu yang akan dikirimkan. (Tampubolon \& Sjani, 2014) menjelakan bahwa besar nilai faktor daya dapat ditentukan dengan persamaan.

$$
\text { Faktor daya }=\cos \varphi=\frac{\text { Daya Aktif }}{\text { Daya Semu }}
$$

Nilai faktor daya tertinggi adalah 1 . Sistem dengan faktor daya seperti ini memiliki efisiensi yang sangat baik dimana hal ini berarti daya total/semu (VA) yang dibangkitkan digunakan secara utuh pada beban resistif (Watt). Dalam hal ini nilai daya total/ semu (VA) sama dengan daya aktif (Watt).

\section{E. Daya Listrik}

(Saadat, 1999) menjelaskan bahwa terdapat 3 (tiga) jenis daya dalam sistem tenaga listrik, yaitu:

1. Daya Aktif (P) dalam satuan Watt

2. Daya Semu (S) dalam satuan VA

3. Daya reaktif $(\mathrm{Q})$ dalam satuan VAR

Daya aktif merupakan daya yang sesungguhnya Daya ini digunakan oleh beban untuk melakukan kerja. Daya ini menghasilkan energi lain sebagai hasil dari kerja yang dilakukan oleh beban. Energi lain yang dihasilkan dapat berupa energi mekanik pada pada kipas angin, energi cahaya pada lampu, dan energi panas pada seterika. Satuan dari daya aktif yaitu Watt (W) atau Horse Power (HP) dimana 1 HP setara dengan 746 watt. (Saadat, 1999; Untamah, 2016) menjelakan secara umum persamaan dari ketiga jenis daya diatas dapat dituliskan sebagai berikut:

Untuk sistem 1 fasa: $P=V \times I \times \cos \varphi$

Untuk sistem 3 fasa: $P=V \times I \times \cos \varphi \times \sqrt{3}$

Keterangan:

$\mathrm{P}$ = Daya aktif dalam satuan Watt (W)

$\mathrm{V}=$ Tegangan dalam satuan Volt $(\mathrm{V})$

$\mathrm{I}=$ Arus dalam satuan Ampere (A)

$\operatorname{Cos} \varphi=$ faktor daya

Daya reaktif merupakan daya yang digunakan oleh beban induktif untuk pembentukan medan magnet pada kumparan-kumparannya. Adapun contoh dari beban reaktif adalah motormotor listrik, transformator, lampu TL, dan peralatan listrik lainnya yang mengandung kumparan-kumparan. Satuan daya reaktif adalah Volt-Ampere Reaktif (VAR). (Saadat, 1999; Untamah, 2016) menjelaskan Untuk menentukan daya reaktif dapat dihutung menggunakan persamaan:

Untuk sistem 1 fasa : $Q=V \times I \times \sin \varphi$

Untuk sistem 3 fasa : $Q=V \times I \times \sin \varphi \times \sqrt{3}$

Keterangan:

$\mathrm{Q}=$ Daya reaktif dalam satuan Volt-Ampere Reaktif (VAR)

$\mathrm{V}=$ Tegangan dalam satuan Volt $(\mathrm{V})$

$\mathrm{I}=$ Arus dalam satuan Ampere (A)

$\sin \varphi=$ Besaran Vektor Daya

Daya semu merupakan daya yang dihasilkan dari perkalian antara tegangan RMS ( $\left.\mathrm{V}_{\mathrm{RMS}}\right)$ dan arus RMS (I $\mathrm{I}_{\mathrm{RMS}}$ ). Tegangan RMS dan arus RMS 
merupakan tegangan dan arus yang mengalir pada jaringan listrik AC. Daya semu memiliki satuan Volt-Ampere (VA). (Gönen, 2008; Saadat, 1999) menjelaskan bahwa besar daya semu dirumuskan dengan persamaan berikut:

Untuk sistem 1 fasa: $S=V \times I$

Untuk sistem 3 fasa: $S=V \times I \times \sqrt{3}$

\section{Keterangan:}

$\mathrm{S}$ = Daya semu dalam satuan Volt-Ampere (VA)

$\mathrm{V}=$ Tegangan dalam satuan Volt $(\mathrm{V})$

$\mathrm{I}=$ Arus dalam satuan Ampere (A)

Menghitung perbaikan faktor daya suatu kapasitor dapat menggunakan metode Segitiga Daya. Metode segitiga daya adalah metode perhitungan yang akan digunakan menggambarkan bagaimana daya reaktif mempengaruhi faktor daya dan pada jaringan ac daya semu total kva diperoleh dengan bantuan hubungan segitiga daya. Menurut (Sirait, n.d.) hubungan segitiga daya ditentukan dengan persamaan berikut:

$S=\sqrt{P^{2}+Q^{2}}$

$P=\sqrt{S^{2}-Q^{2}}$

$Q=\sqrt{S^{2}-P^{2}}$

\section{Keterangan:}

$\mathrm{S}$ = Daya semu dalam satuan Volt Ampere (VA)

$\mathrm{P}=$ Daya aktif dalam satuan Watt $(\mathrm{W})$

$\mathrm{Q}=$ Daya reaktif dalam satuan Volt Ampere Reaktif (VAR)

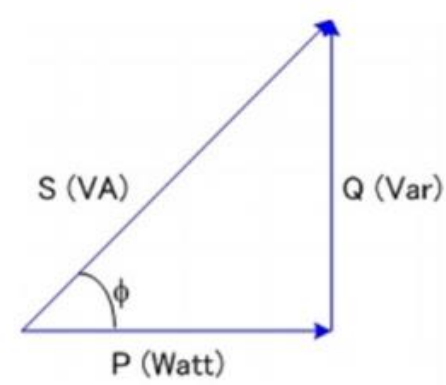

Gambar 1. Segitiga Daya

\section{METODE}

Penelitian ini membahas tentang pengaruh penggunaan kapasitor bank pada penyulang kota PT. PLN (Persero) Rayon Meulaboh Kota. Penelitian ini merupakan penelitian kuantitatif dengan membandingkan data hasil pengukuran pada saat kapasitor bank hidup (on) dan pada saat kapasitor mati (off).

Pengukuran dilakukan sebanyak 7 (tujuh) kali kemudian dibandingkan pada saat kapasitor bank on dan off. Setelah itu dilakukan perhitungan secara matematis dan dianalisa data yang sudah didapatkan.

\section{A. Perhitungan Faktor Daya $(\cos \varphi)$}

Faktor daya didefinisikan sebagai perbandingan antara arus yang menghasilkan kerja di dalam suatu rangkaian terhadap arus total yang masuk ke dalam rangkaian atau dapat dikatakan sebagai perbandingan daya aktif (P) dan daya semu (S).

$$
\text { Faktor daya }=\frac{\text { Daya Aktif }}{\text { Daya Semu }}
$$

Hubungan antara faktor daya (power factor) dengan daya semu (apparent power) diperkenalkan oleh kalangan industri penyedia daya listrik, dalam upaya menyalurkan energi listrik dari satu titik ke titik lain. Proses distribusi daya listrik yang efektif dan efisien ini terkait langsung biaya produksi energi listrik yang pada akhirnya akaan dibebankan kepada pengguna energi listrik sebagai konsumen. Hal yang memiliki pengaruh penting dalam perpindahan energi listrik tersebut adalah faktor daya. Untuk mencapai efesiensi penyaluran energi yang maksimal dengan persentae $100 \%$, maka rangkaian harus memiliki nilai faktor daya mendekati atau sama dengan 1 (Noor et al., 2017).

\section{B. Segitiga Daya}

Persamaan untuk menghitung hubungan antara daya aktif, daya reaktif dan daya semu dikenal dengan persamaan segitiga daya:

$$
S=\sqrt{P^{2}+Q^{2}}
$$

\section{HASIL DAN PEMBAHASAN}

Perbandingan beban dilakukan pada kondisi kapasitor bank off dan on. Hal ini dilakukan untuk melihat pengaruh penggunaan kapasitor bank pada penyulang kota di PT. PLN (Persero) Rayon Meulaboh Kota. Perbandingan dilakukan menggunakan data hasil pengkuran pada saat beban puncak pukul 20.00 selama 7 (tujuh) hari. 


\section{A. Daya Aktif (P) pada saat Kapasitor Bank OFF}

Tabel 1. Daya beban puncak penyulang kota pada saat kapasitor bank OFF

\begin{tabular}{|c|c|c|c|c|c|}
\hline \multirow{2}{*}{ Feeder } & Pengukuran & Pukul & $\begin{array}{c}\text { Arus } \\
(\mathbf{k A})\end{array}$ & $\begin{array}{c}\text { Tegangan } \\
(\mathbf{k V})\end{array}$ & $\begin{array}{c}\text { Daya } \\
(\mathbf{k W})\end{array}$ \\
\hline \multirow{4}{*}{$\begin{array}{c}\text { Penyulang } \\
\text { Kota }\end{array}$} & I & 20.00 & 54 & 20 & 1569,45 \\
\cline { 2 - 6 } & II & 20.00 & 57 & 20 & 1676,37 \\
\cline { 2 - 6 } & III & 20.00 & 61 & 20 & 1794,01 \\
\cline { 2 - 6 } & IV & 20.00 & 64 & 20 & 1882,24 \\
\cline { 2 - 6 } & V & 20.00 & 57 & 20 & 1676,37 \\
\cline { 2 - 6 } & VI & 20.00 & 50 & 20 & 1297,5 \\
\cline { 2 - 6 } & VII & 20.00 & 59 & 20 & 1714,77 \\
\hline
\end{tabular}

Menghitung faktor daya $(\cos \varphi)$ dari data hasil pengukuran pada table 1 di atas. Perhitungan dengan persamaan:

$$
\text { Faktor daya }=\frac{\text { Daya Aktif }}{\text { Daya Semu }}
$$

Daya aktif dapat dilihat pada data hasil pengukuran sementara daya semu dapat dihitung dengan persamaan:

$$
S=\sqrt{3} \times V \times I
$$

Adapun perhitungan nilai faktor daya pada pengukuran ke-1 adalah sebagai berikut:

$$
\begin{aligned}
\cos \varphi & =\frac{\mathrm{P}}{\sqrt{3 \times \mathrm{V} \times \mathrm{I}}} \\
\cos \varphi & =\frac{1569,45}{\sqrt{3 \times 20 \times 54}} \\
& =0,84
\end{aligned}
$$

Adapun hasil perhitungan nilai $\cos \varphi$ untuk

\begin{tabular}{|c|c|c|c|c|c|c|}
\hline Feeder & Peng & Pukul & $\begin{array}{c}\text { Arus } \\
(\mathbf{k A})\end{array}$ & $\begin{array}{c}\text { Tegangan } \\
(\mathrm{kV})\end{array}$ & $\begin{array}{l}\text { Daya } \\
(\mathbf{k W})\end{array}$ & $\operatorname{Cos} \varphi$ \\
\hline \multirow{7}{*}{$\begin{array}{c}\text { Penyulang } \\
\text { Kota }\end{array}$} & I & 20.00 & 54 & 20 & 1569,45 & 0,84 \\
\hline & II & 20.00 & 57 & 20 & 1676,37 & 0,85 \\
\hline & III & 20.00 & 61 & 20 & 1794,01 & 0,85 \\
\hline & IV & 20.00 & 64 & 20 & 1882,24 & 0,85 \\
\hline & $\mathrm{V}$ & 20.00 & 57 & 20 & 1676,37 & 0,85 \\
\hline & VI & 20.00 & 50 & 20 & 1297,5 & 0,75 \\
\hline & VII & 20.00 & 59 & 20 & 1714,77 & 0,84 \\
\hline \multicolumn{5}{|r|}{ Rata-rata } & 1658.67 & 0,83 \\
\hline
\end{tabular}
pengukurang berikutnya dapat dilihat pada table 2 berikut.

Tabel 2. Data nilai faktor daya $(\cos \varphi)$ pada hasil pengukuran kondisi kapasitor bank OFF

\section{B. Daya Aktif (P) Pada Saat Kapasitor Bank ON}

Menghitung besar daya aktif (P) pada saat kapasitor bank ON menghasilkan perbaikan faktor daya sebesar 0,95. Daya aktif dapat dihitung dengan persamaan:

$$
P=V \times I \times \cos \varphi \times \sqrt{3}
$$

Daya aktif pada pengukuran ke-1 dengan $\mathrm{V}$ $=20 \mathrm{kV}$ dan Arus $\mathrm{I}=54 \mathrm{kA}$ adalah sebagai berikut.

$$
\begin{gathered}
P=20 \times 54 \times 0,95 \times \sqrt{3} \\
=1777,08 \mathrm{~kW}
\end{gathered}
$$

\begin{tabular}{|c|c|c|c|c|c|c|}
\hline Feeder & Peng & Pukul & $\begin{array}{r}\text { Arus } \\
(\mathbf{k A})\end{array}$ & $\begin{array}{c}\text { Tegangan } \\
(\mathrm{kV})\end{array}$ & $\begin{array}{l}\text { Daya } \\
(\mathrm{kW})\end{array}$ & $\operatorname{Cos} \varphi$ \\
\hline \multirow{7}{*}{$\begin{array}{c}\text { Penyulang } \\
\text { Kota }\end{array}$} & I & 20.00 & 54 & 20 & 1774,98 & 0, \\
\hline & II & 20.00 & 57 & 20 & 1873,59 & 0,95 \\
\hline & III & 20.00 & 61 & 20 & 2005,07 & 0,95 \\
\hline & IV & 20.00 & 64 & 20 & 2103,68 & 0,95 \\
\hline & $\mathrm{V}$ & 20.00 & 57 & 20 & 1873,59 & 0,95 \\
\hline & VI & 20.00 & 50 & 20 & 1643,5 & \begin{tabular}{|l|}
0,95 \\
\end{tabular} \\
\hline & VII & 20.00 & 59 & 20 & 1939,33 & \begin{tabular}{|l|}
0,95 \\
\end{tabular} \\
\hline \multicolumn{5}{|c|}{ Daya Rata-rata } & 8887.67 & \\
\hline
\end{tabular}

Dilakukan perhitungan Daya yang sama untuk pengukuran berikutnya. Adapun hasil perhitungan daya aktif pada saat kapasitor bank ON dapat dilihat pada table 3 berikut.

Tabel 3. Hasil Perhitungan daya aktif (P) saat beban puncak dengan kapasitor bank ON dan faktor daya 0,95

Dari table 3 diatas dapat dilihat bahwa besar daya Aktif meningkat pada saat kapasitor bank ON. Perbandingan daya aktif ketika kapasitor bank OFF dan ON dapat dilihat pada gambar 1 berikut.

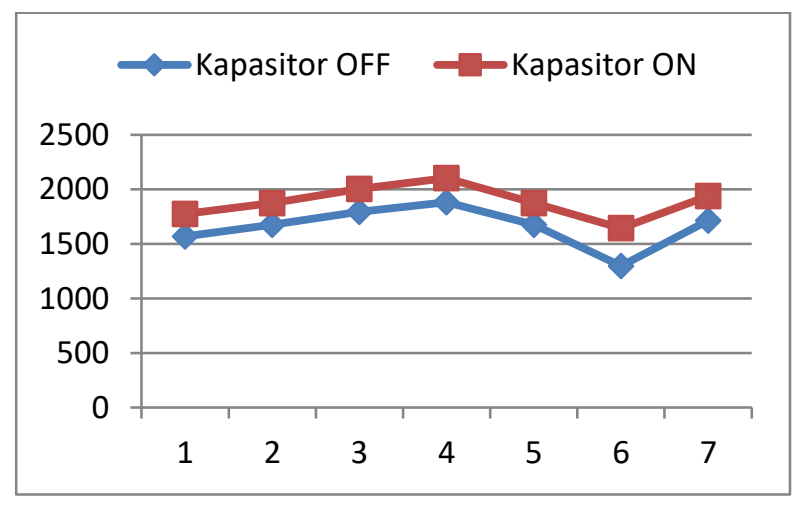

Gambar 1. Grafik Perbandingan Besar Daya Aktif ketika Kapasitor Bank OFF dan ON

Dari gambar 1 diatas dapat dilihat bahwa nilai rata-rata daya aktif pada saat kapasitor ON menigkat berbanding dengan ketika kapasitor OFF. Dari hasil perhitungan didapat nilai rata-rata daya aktif ketika kapasitor bank OFF sebesar 1658,67 kW. Sementara daya aktif ketika kapasitor bank ON adalah sebesar $1887.67 \mathrm{~kW}$. Pesentase kenaikan nilai rata-rata daya aktif adalah sebesar $12,1 \%$. 


\section{Perhitungan Daya Semu}

Daya semu (S) merupakan daya yang dihasilkan oleh pembangkit listrik PT. PLN (Persero). Daya ini lah yang didistribusikan kepada pelanggan. Besar daya semu dapat ditentukan dengan mengalikan nilai tegangan dan arus dari hasil pengukuran.

$$
S=V \times I \times \sqrt{3}
$$

Dengan menggunakan formula di atas, dari hasil pengukran ke-1, besar nilai daya semu dapat ditentukan:

$$
\begin{aligned}
S & =20 \times 54 \times \sqrt{3} \\
& =1868,4 \mathrm{kVA}
\end{aligned}
$$

Adapun data hasil perhitungan daya semu keseluruhan dapat dilihat pada table 4 berikut.

\begin{tabular}{|c|c|c|c|c|c|}
\hline Feeder & Pengukuran & Pukul & $\begin{array}{r}\text { Arus } \\
\text { (kA) }\end{array}$ & $\begin{array}{c}\text { Tegangan } \\
(\mathbf{k V})\end{array}$ & $\begin{array}{l}\text { Daya } \\
\text { Semu } \\
\text { (kVA) }\end{array}$ \\
\hline \multirow{7}{*}{$\begin{array}{c}\text { Penyulang } \\
\text { Kota }\end{array}$} & I & 20.00 & 54 & 20 & 1868,4 \\
\hline & II & 20.00 & 57 & 20 & 1972,2 \\
\hline & III & 20.00 & 61 & 20 & 2110,6 \\
\hline & IV & 20.00 & 64 & 20 & 2214,4 \\
\hline & $\mathrm{V}$ & 20.00 & 57 & 20 & 1972,2 \\
\hline & VI & 20.00 & 50 & 20 & 1730 \\
\hline & VII & 20.00 & 59 & 20 & 2041,4 \\
\hline
\end{tabular}

Tabel 4. Data hasil perhitungan daya semu pada saat beban puncak

\section{Daya Reaktif (Q) Pada Saat Kapasitor Bank OFF}

Perhitungan daya reaktif pada kondisi kapasitor bank OFF dilakukan dengan menggunakan persamaan segitiga daya. Besar nilai daya reaktif adalah sebagai berikut.

Pengukuran ke-1

$Q=\sqrt{S^{2}-P^{2}}$

$Q=\sqrt{1868,4^{2}-1569,45^{2}}$

$Q=1013,77 \mathrm{kVAR}$

Untuk hasil perhitungan lengkap daya reaktif dapat dilihat pada table 5 dibawah ini.

Tabel 5. Daya Reaktif kondisi kapasitor bank OFF pada saat beban puncak

\begin{tabular}{|c|c|c|c|c|c|c|}
\hline Peng & Pukul & $\begin{array}{c}\text { I } \\
(\mathbf{k A})\end{array}$ & $\begin{array}{c}\text { V } \\
(\mathbf{k V})\end{array}$ & $\mathbf{P}(\mathbf{k W})$ & $\begin{array}{c}\text { S } \\
(\mathbf{k V A})\end{array}$ & $\begin{array}{c}\mathbf{Q} \\
(\mathbf{k V A R})\end{array}$ \\
\hline I & 20.00 & 54 & 20 & 1569,45 & 1868,4 & 1013,77 \\
\hline II & 20.00 & 57 & 20 & 1676,37 & 1972,2 & 1038,92 \\
\hline III & 20.00 & 61 & 20 & 1794,01 & 2110,6 & 1111,82 \\
\hline IV & 20.00 & 64 & 20 & 1882,24 & 2214,4 & 1166,12 \\
\hline V & 20.00 & 57 & 20 & 1676,37 & 1972,2 & 1038,92 \\
\hline VI & 20.00 & 50 & 20 & 1297,5 & 1730 & 780,63 \\
\hline
\end{tabular}

\begin{tabular}{|c|c|c|c|c|c|c|}
\hline VII & 20.00 & 59 & 20 & 1714,77 & 2041,4 & 1057,05 \\
\hline \multicolumn{8}{|c|}{ Daya reaktif rata-rata } & 1029.60 \\
\hline
\end{tabular}

\section{E. Daya Reaktif (Q) Pada Saat Kapasitor Bank ON}

Selanjutnya dilakukan perhitungan daya reaktif ketika kapasitor bank ON pada saat beban puncak. Nilai daya reaktif dapat ditentukan dengan persamaan segitiga daya berikut.

Pengukuran ke-1

$Q=\sqrt{S^{2}-P^{2}}$

$Q=\sqrt{1868,4^{2}-1774,98^{2}}$

$Q=583,40 \mathrm{kVAR}$

Untuk perhitungan nilai daya reaktif pada data pengukuran berikutnya dapat dilihat pada tabel 6 berikut.

\begin{tabular}{|c|c|c|c|c|c|c|}
\hline Peng & Pukul & $\begin{array}{c}\mathbf{I} \\
(\mathbf{k A})\end{array}$ & $\begin{array}{c}\mathbf{V} \\
(\mathbf{k V})\end{array}$ & $\begin{array}{c}\mathbf{P} \\
(\mathbf{k W})\end{array}$ & $\begin{array}{c}\mathbf{S} \\
(\mathbf{k V A})\end{array}$ & $\begin{array}{c}\mathbf{Q} \\
(\mathrm{kVAR})\end{array}$ \\
\hline I & 20.00 & 54 & 20 & 1569,45 & 1868,4 & 583,40 \\
\hline II & 20.00 & 57 & 20 & 1676,37 & 1972,2 & 615,81 \\
\hline III & 20.00 & 61 & 20 & 1794,01 & 2110,6 & 659,03 \\
\hline IV & 20.00 & 64 & 20 & 1882,24 & 2214,4 & 690,80 \\
\hline $\mathrm{V}$ & 20.00 & 57 & 20 & 1676,37 & 1972,2 & 615,81 \\
\hline VI & 20.00 & 50 & 20 & 1297,5 & 1730 & 540,19 \\
\hline VII & 20.00 & 59 & 20 & 1714,77 & 2041,4 & 544,79 \\
\hline \multicolumn{6}{|c|}{ Daya reaktif rata-rata } & 607.11 \\
\hline
\end{tabular}

Tabel 6. Daya Reaktif kondisi kapasitor bank ON pada saat beban puncak

Dari table 6 diatas dapat dilihat bahwa besar daya reaktif menurun pada saat kapasitor bank ON. Perbandingan penurunan daya reaktif ketika kapasitor bank OFF dan ON ditunjukkan pada gambar 2 berikut.

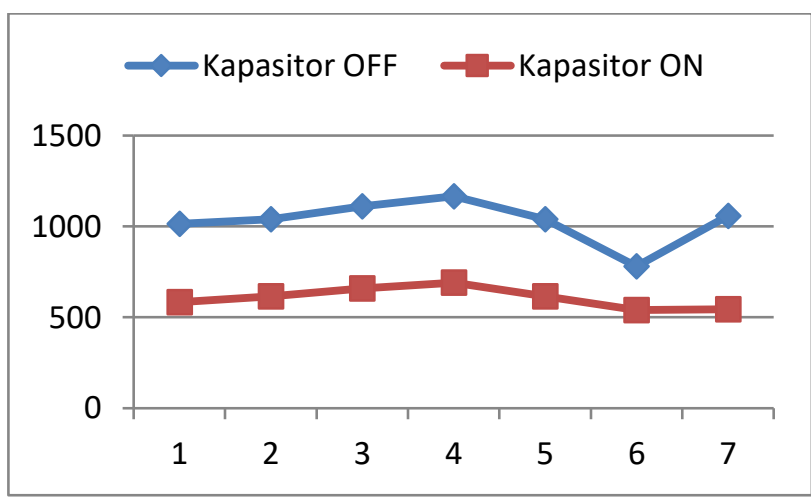

Gambar 2. Grafik Perbandingan Daya Reaktif pada Saat Kapasitor Bank OFF dan ON

Dari gambar 2 diatas dapat dilihat bahwa nilai rata-rata daya reaktif pada saat kapasitor ON 
mengalami penurunan berbanding ketika kapasitor OFF. Dari hasil perhitungan didapat nilai rata-rata daya reaktif ketika kapasitor bank OFF sebesar 1029,60 kVAR. Sementara daya reaktif ketika kapasitor bank ON adalah sebesar 607,11 kVAR. Pesentase penurunan nilai rata-rata daya reaktif adalah sebesar $41,03 \%$.

\section{KESIMPULAN}

Dari hasil penelitian ini dapat diambil beberapa kesimpulan diantaranya:

1. Penggunaan kapasitor bank yang dipasang secara paralel pada beban penyulang kota sangat efektif dalam meningkatkan daya aktif dengan nilai rata-rata $1887,67 \mathrm{~kW}$ mendekati daya semu rata-rata sebesar 1987,02 kVA

2. Persentase kenaikan daya aktif pada saat kapasitor bank OFF dan ON adalah sebesar $12,1 \%$.

3. Persentase penurunan daya reaktif pada saat kapasitor bank OFF dan ON adalah sebesar $41,03 \%$.

4. Penggunaan kapasitor bank pada penyulang kota juga dapat memperbaiki nilai faktor daya dari 0,83 menjadi 0,95 .

\section{DAFTAR PUSTAKA}

Almanda, D., \& Majid, N. (2019). Studi Analisa Penyebab Kerusakan Kapasitor Bank Sub Station Welding di PT. Astra Daihatsu Motor. RESISTOR (ElektRonika KEndali TelekomunikaSI Tenaga LiSTrik KOmputeR), 2(1), 7-14.

Gönen, T. (2008). Electric power distribution system engineering (Vol. 2). CRC press Boca Raton.

Kersting, W. H. (1991). Radial distribution test feeders. IEEE Transactions on Power Systems, 6(3), 975-985.

Noor, F. A., Ananta, H., \& Sunardiyo, S. (2017). Pengaruh Penambahan Kapasitor Terhadap Tegangan, Arus, Faktor Daya, dan Daya Aktif pada Beban Listrik di Minimarket. Jurnal Teknik Elektro, 9(2), 66-73.

PRABOWO, A. T. (2016). Studi Penempatan Kapasitor Untuk Perbaikan Kualitas Tegangan Di Penyulang Kangkung GI Menggala.

Saadat, H. (1999). Power system analysis.
WCB/McGraw-Hill.

Sirait, L. S. (n.d.). Studi Evaluasi Pemasangan Kapasitor Bank Pada Sistem Kelistrikan Pusat Perbelanjaan A. Yani Megamal Pontianak. Jurnal Teknik Elektro Universitas Tanjungpura, 2(1). Syufrijal. (2014). Jaringan Distribusi Tenaga Listrik paket Keahlian Teknik Ketenagalistrikan. Kementerian Pendidikan Dasar Menengah Dan Kebudayaan Republik Indonesia. Tampubolon, D., \& Sjani, M. (2014). Optimalisasi Penggunaan Kapasitor Bank Pada Jaringan 20 KV Dengan Simulasi ETAP (Studi Kasus Pada Feeder Srikandi di PLN Rayon Pangkalan Balai, Wilayah Sumatera Selatan). Singuda Ensikom, 9(2), 62-67.

Untamah, O. V. I. (2016). Studi Penggunaan Kapasitor Bank Pada Semen Mill Indarung Ii Pt. Semen Padang. Politeknik Negeri Padang. 